\title{
Implementation of Character Education in the Content of Citizenship Education Lessons on Efforts to Prevent Moral Decadence
}

\author{
Ratmiyati ${ }^{1}$, Ana Andriani ${ }^{2}$

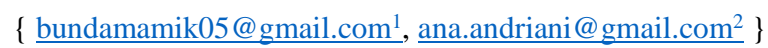 \\ ${ }^{1,2}$ Magister Pendidikan Dasar, Universitas Muhammadiyah Purwokerto, Jl KH Ahmad \\ Dahlan, Banyumas 53182, Indonesia ${ }^{1}$
}

\begin{abstract}
The phenomenon of moral deviation in children is an indication of affective values, such as the decline in morality seen in today's youth. This study aims to determine how the implementation of character education in the content of citizenship education lessons towards prevention of moral decadence for students of class VI SDN 1 Brecek Kec. Kaligondang Purbalingga. This study uses a descriptive analytical qualitative method, which is a research method that describes events that are actual and occur when the research is in progress. Analytical descriptive qualitative method is used to describe and interpret objects according to what they are analytically, through interviews with the unit of analysis, namely two Citizenship Education teachers at SDN 1 Brecek Kaligondang Purbalingga. This study concludes: First, the role of teachers in the implementation of character education in the content of citizenship education lessons in preventing students' moral decadence. Second, the approach or method of learning the character education process used by teachers in an effort to prevent students' moral decadence. Third, solutions or problem solving to the obstacles faced by teachers in the character education process in an effort to prevent students' moral decadence.
\end{abstract}

Keywords: Character Education, Moral Decadence

\section{Introduction}

The negative impact of education does not combine cognitive with affective or the lack of affective / character values in education [1]. Furthermore, science and technology and modernization in a globalistic life without moral values will cause erosion of intellectual, cultural and spiritual morals as well as cause demoralization and moral decadence.

The assumption that occurs in children, namely the existence of moral deviations is an indication that affective values do not take root in the soul or heart of the child. This phenomenon does not only occur in other countries but also in our country, such as the decline in morality seen in our youth [2]. Characteristics of early adolescence presented by Daradjat, Z, After the 12-year-old child (grade VI) moved from childhood which was known to be calm, not much debate and questions, they entered a period of shock, because of their rapid growth in all fields, their feelings of turmoil were unstable. belief in God is sometimes very strong. Sometimes it becomes doubtful the worship is sometimes diligent and sometimes lazy. [3]

The education that is held in schools tends to be partially lacking in integrating affective values. H.A.R. Tilaar said that our education today is very "intellectualistic", meaning that it only prioritizes one element. [4]. Ki Hadjar Dewantara indicated that education today, that there 
is only the air of "intellectualism" which kills human feelings that are merely concerned with numbers. Meanwhile, character education is taught only casually. [5].

The phenomenon of education in schools in educating students, cognitive aspects are more dominant than affective, it appears that parents feel restless if their children are not good at exact science, while low scores other than exact (social) subjects are not a problem. Education that overrides affective values (character) occurs a lot of decadence / decline, moral deviation, especially among students, marked by the emergence of destructive or destructive behavior. This deviation is a dull or not developed character properly.

Education in schools determines the future of students and the culture that is absorbed, becomes the basis for the formation of further character or character. Fostering character is not enough with words alone but needs real implementation, examples and examples from all school apparatus, especially by teachers, especially Civics teachers. A conducive school environment, calm, safe atmosphere and full of religious and cultural values such as good examples and examples that reflect the noble values of peace, courtesy, warmth, empathy, and so on are steps to develop character education.

Character education as a pedagogy pays important attention to human growth, namely the development of natural human abilities as possessed differently by each individual (naturalist). In developing this natural ability, humans cannot ignore their negative relations with the social environment and in this relationship between individuals and society, humans direct themselves to values. Good character is what we want our children to do. A Greek philosopher named Aristotle, as quoted by Lickona, defines good character as life by doing right actions in respect of oneself and others. [6]

Aristotle's writings remind us of what we tend to do today: a virtuous life includes selforiented goodness as well as other things-oriented goodness (such as generosity and compassion), and both types of kindness relate. Or in other words, we need to control ourselves, and to do good things for others. Thus, students need character education that will shape the character of a student.

Chang said that there are 3 (three) reasons why schools fail to socialize moral values to their students. The reasons are as follows [7]: First, the cultivation of moral values in the world of formal education is generally still a set of raw theories, apart from the realities of people's lives. Less explored the roots of the connection between the cultivation of moral values and the practice of moral life in society. Second, as a formal institution that prepares students to act and transform themselves according to moral values, it turns out that the school does not have a close cooperation network with the students' families of origin, government agencies, nongovernment agencies and the entire community. Third, there is a gap in the outlook on life between those who uphold and abuse moral messages in their daily social life. For example, there are still growing social groups that justify and approve of all means and roads to achieve the stated targets, for example, the activities of the dawn attack during elections, paying police officers for traffic violations (not wearing helmets, not extending vehicle taxes, etc.). [7]

This is if a further look at the various problems of moral decadence or the decline in moral values and character and the factors that cause students to carry out various forms and types of activities that violate both during school hours, and outside school hours, are including the lack of strict application of school discipline rules, frequent empty lesson hours that are not filled with other school support activities, security guards / guard teachers who are less assertive in admonishing students, school gate gates are not functioning, and students' moral guidance is less effective both in the family environment, society and at school. 
The large number of students "hanging around" and the decline in student morale shows that there is still not steady integration in the management of the learning system in schools. The management of an integrated learning system requires a linkage between intracurricular activities and extracurricular activities in an education system, especially in this case that is associated with the implementation of character education in the learning process in schools.

The implementation of character education in school education units is influenced by two main factors, namely internal factors and external factors. Internal school factors include: the role of the principal, school discipline, existence of a syllabus, a supportive curriculum, student integrity, teacher discipline, teacher professionalism, supporting school infrastructure, school vision and mission, student discipline, employee integrity, application of sanctions. for those who violate the strict rules and regulations and commitment of school members to fostering and educating the nation's character Meanwhile, the external factors of the school include: the condition of the school environment, the condition of the community outside the school, the culture of the surrounding community, the family environment, and the role of community leaders.

Some research questions are as follows: 1) How is the implementation of character education in the content of citizenship education lessons on efforts to prevent moral decadence of students in class VI SD N 1 Brecek, Kaligondang District, Purbalingga Regency ?; 2) What is the approach or learning method for character education used by Civics teachers in an effort to prevent student moral decadence at SDN 1 Brecek Kaligondang Purbalingga?; 3) What are the solutions or solutions to problems faced by Civics teachers in the process of implementation of character education in the content of citizenship education lessons on efforts to prevent moral decadence of students in class VI SD N 1 Brecek, Kaligondang District, Purbalingga Regency?

\section{Research Methods}

The method used in this research is correlational descriptive method using quantitative approaches, which describes the relationship between character education and efforts to prevent student moral decadence. According to Nana Sudjana and Ibrahim, what is meant by descriptive research is "research that tries to describe a symptom, event, event that is happening at the moment". This research approach is used to test the hypotheses that have been set [8]. Sugiyono explained that quantitative research methods can be interpreted as research methods based on the philosophy of positivism, used to research specific populations or samples, sampling techniques are generally carried out randomly, data collection using research instruments, quantitative / statistical data analysis with the aim of test the hypothesis that has been set [9]

Sudjana, N and Ibrahim explained about the meaning of the correlational research method. Correlation studies study the relationship between two or more variables, namely the extent to which variations in one variable are related to variations in other variables [8]. This is in line with Syaodih's "associational study, also called a correlational study, which examines the relationship between two things, two or more variables [10].

In this study, the researcher wanted to see the relationship between two variables without trying to change or treat these variables. Research variables according to Sugiyono "... The research variables are basically anything in the form determined by the researcher to be studied in order to obtain information about it, then draw conclusions." [9]

This study discusses two variables, namely the independent variable and the dependent variable. The independent variable is a variable that affects or causes the change or the emergence of the dependent variable. Meanwhile, the dependent variable is the variable that is influenced or becomes the result, because of the independent variable. In this study, the 
independent variable $(\mathrm{X})$. In this study, the independent variable $(\mathrm{X})$ is character education and the dependent variable $(\mathrm{Y})$ is the prevention of moral decadence in grade $\mathrm{V}$ and VI SD students.

\section{Discussion}

3.1 The role of Civics / Classroom teachers in character education in efforts to prevent student moral decadence at SDN 1 Brecek

Moral decadence is deterioration, deviance, shift in student morale, which begins with activities violating discipline, lack of discipline, lack of respect for teachers and parents, unable to cooperate with group friends, dressed in dirty uniforms, use of accessories. excessive, skipping school, taxing fellow friends (malak), feeling strong and powerful, smoking at school, pornographic acts, disturbing the surrounding environment, polluting the environment and so on.

The factors that cause moral decline / moral decadence that cause moral shifts are actually many, among others, the most important ones are: 1) The lack of spirituality in each person in society (highlighting the aspect of religion); 2) The condition of society is less stable, both in terms of economy, social and politics (highlighting aspects of Pancagatra); 3) Moral education is not carried out accordingly, either at home, at school or in the community (highlighting cultural aspects); 4) Poor household atmosphere (highlighting economic aspects); 5) Popular introduction of anti-pregnant drugs and devices (legal aspect highlight); 6) The number of writings, pictures, broadcasts, arts that do not heed moral basics and demands (highlighting aesthetic aspects); 7) Lack of guidance to fill leisure time (leisure time) in a good way, and which leads to moral development (highlighting ethical aspects); 8) Absence or lack of counseling and outreach centers for children and youth (legal aspects highlight).

Starting from the answers to the results of the research above, the research findings show that the role of Civics Teachers/Class Teachers in character education (morality) in preventing students' moral decadence has a very important role. In addition to the moral norms in schools, character education is also integrated with all other subject matter. However, character education is also a shared duty and obligation, both subject teachers, school principals, administration to school guards have the obligation to foster character values (character) [1][3].

Civics / classroom teachers have a major role in instilling moral values in an effort to prevent moral decadence, this is linked to law. No. 20 of 2003 concerning the National Education System, the explanation of article 37 is "intended to shape students into human beings who have a sense of nationality and love the country" and article 3 on the functions and objectives of national education, namely "National education functions to develop abilities and shape character and civilization. a dignified nation in the framework of the intellectual life of the nation, aims to develop the potential of students to become human beings who believe and fear God Almighty, have noble character, are healthy, knowledgeable, capable, creative, independent, and become democratic and responsible citizens. ". [11]

\subsection{The approach or character education learning method used by Civics teachers / classroom teachers in an effort to prevent student moral decadence at SDN 1 Brecek}

Based on the results of the interview above, the research findings show that the learning approaches that can be used by Civics / Classroom Teachers are varied, not limited to conventional learning approaches, namely lectures, but visualization learning approaches in the form of pictures / photos, varied discussions through learning learning patterns. groups or 'cooperative learning'. 
The need for a varied learning approach is so that students can easily understand the meaning of the message content values-moral-character norms (character) so that it is hoped that efforts to prevent students' moral decadence behavior can be achieved as expected. A varied learning approach pattern is also needed so that students do not quickly feel bored / bored in learning, so that if the learning feels bored, it will make it difficult for the teacher to apply the character education process [12].

\subsection{Solutions or solutions to problems faced by Civics / Classroom teachers in the character education process in an effort to prevent student moral decadence at SDN 1 Brecek}

Based on the results of the interview above, the research findings show that the solution or problem solving to the obstacles faced by Civics / Classroom Teachers in the process of character education (character) in an effort to prevent student moral decadence, in principle lies in the sensitivity or sensitivity of the teacher in each perceived activity. strange 'or' different 'from what usually happens in student life, which begins in class activities. Starting from the sensitivity of the teacher's feelings, the teacher can follow up by taking a personal approach with the student concerned, then making reports to the homeroom teacher and the BP / BK teacher to be handled collectively, so that problems can be more easily resolved, especially in behavioral efforts. further which will result in bad behavior that is not expected which is more than moral decadence, namely crime, alcohol and even drugs [12].

The next steps that should be taken by Civics / Classroom Teachers in the teaching and learning process in the classroom are: 1) able to present learning material in an attractive manner so that it attracts students' interest to learn and understand it;2) the use of appropriate and varied learning media; 3) visualization learning approaches, role playing, varied discussions with group learning patterns. Some of these efforts were made to prevent student learning boredom, so that if students feel happy learning it will be easier to grasp the meaning of the message content of moral values of ethical norms to be conveyed to students, and if students can easily grasp the meaning of the content of the message. , then efforts to prevent student moral decadence behavior will be easily achieved in accordance with the expectations of the national education system Law no. 20 of 2003. [11]

School activity programs that are carried out for character education in an effort to prevent student moral decadence include: 1) getting used to attitudes and behaviors in accordance with the teachings of noble character; 2) carrying out religious worship; 3) carry out activities to commemorate religious holidays; 4) develop self-confidence for the sake of developing independence; 5) fostering teachers and other education personnel; 6) invite resource persons, religious leaders, Civics experts, ethics experts to discuss material about noble character which can provide insight to students and other school members with the hope of implementing it in the school environment and the surrounding community [13].

For this very important role, but of course very heavy, it requires professional teacher competence, where the teacher can act as a learning facilitator, mediator and learning motivator, so that it can provide facilities or means for students to easily interpret each learning material delivered by teachers, it is understood the vision-mission-objectives of character education, the meaning of the message content of the norms of moral values. Of course, in turn this educational process effort will have an impact on efforts to prevent student moral decadence behavior. 


\section{Conclusions}

Some of the findings and conclusions of the research on "Implementation of Character Education in the Content of Citizenship Education Lessons on Efforts to Prevent Moral Decadence for Class VI Students of SDN 1 Brecek, Kaligondang Subdistrict, Purbalingga ", are as follows: (1) the class teacher / Civics teacher plays the first and main role in the educational process of fostering character values (morals); (2) they should used the approach or method of learning the character education process (character) used by Civics teachers / classroom teachers efforts to prevent students' moral decadence; (3) they should used appropriate learning media; and (4) coordinating with teachers and parents through homeroom teachers and $\mathrm{BK} / \mathrm{BP}$ teachers.

\section{References}

[1] Permatasari DR. Pengaruh Model Pembelajaran Value Clarification Technique (VCT) Tipe Percontohan Terhadap Prestasi Belajar Dan Tanggung Jawab Materi Globalisasi. Dinamika Jurnal Ilmiah Pendidikan Dasar. 2019 Feb 6;9(1).

[2] Dewantoro A, Sartono KE. The influence of value clarification technique (VCT) learning model on homeland attitude at elementary school. Science Rise: Pedagogical Education. 2019 Oct 8(5 (32)):23-31.

[3] Putra GD. Studi Deskriptif Penerapan Pendidikan Karakter Anak Tunagrahita Sedang di Sekolah Dasar Luar Biasa. Dinamika Jurnal Ilmiah Pendidikan Dasar. 2019 Feb 12;10(1).

[4] Tilaar HAR. Beberapa agenda reformasi pendidikan nasional dalam perspektif abad 21. IndonesiaTera; 1998.

[5] Tilaar HAR. Pendidikan Untuk Masyarakat Indonesia Baru. Jakarta: Grasindo. 2002.

[6] Lickona Thomas. Mendidik untuk Membentuk Karakter Bagaimana Sekolah dapat Memberikan Pendidikan Tentang Sikap Hormat dan Tanggung Jawab, Terj. Juma Abdu Wamaungo. Jakarta: Bumi Aksara. 2012.

[7] Sudaryono S, Aryani IK. School Policy in Improving Discipline Character of Elementary School Students. Dinamika Jurnal Ilmiah Pendidikan Dasar. 2021 Sep 22;13(2):101-3.

[8] Sudjana, N dan Ibrahim. Penelitian dan Penilaian Pendidikan. Bandung: Sinar Baru Algensindo. 2007.

[9] Sugiyono. Metode Penelitian Kuantitatif, Kualitatif dan R \&D. Bandung: Alfabeta. 2008.

[10] Sukmadinata, Nana Syaodih. Metode Penelitian Pendidikan, Cet.12 . Bandung: Remaja Rosdakarya. 2017.

[11] Undang-undang RI No. 20 Tahun 2003 Tentang Sistem Pendidikan Nasional. Jakarta.

[12] Megawangi R. Pengembangan program pendidikan karakter di sekolah: pengalaman sekolah karakter. Jakarta: Indonesia Heritage Foundation (IHF). 2010 Nov.

[13] Hermita N, Wijaya TT, Fauza N, Mulyani EA, Alim JA, Putra RA. The Important of the Community of Practice (CoP) in Improving the Primary School Teachers' Performance in Riau Province. Dinamika Jurnal Ilmiah Pendidikan Dasar. 2021 Apr 1;13(1):26-31. 